\title{
E- PROBLEM BASED LEARNING (E-PBL) PADA MATA KULIAH AKUNTANSI MANAJEMEN SEBAGAI ALTERNATIF PEMBELAJARAN INOVATIF
}

\author{
Aniek Murniati \\ Aditya Hermawan \\ Dosen STIE ASIA Malang
}

\begin{abstract}
ABSTRAKSI
Terbatasnya waktu pembelajaran yang hanya 150 menit atau setara dengan 3 SKS pada matakuliah Akuntansi Manajemen menuntut dikembangkannya metode pembelajaran yang lebih inovatif. E-Problem Based Learning (e-PBL) memberikan jawaban atas tuntutan tersebut dengan metode pembelajaran yang lebih inovatif. Penelitian ini merupakan jenis penelitian kualitatif dengan pendekatan interpretif, dimana realita social menjadi dasar model e-PBL. Realita social yang terjadi dalam penelitian ini berupa perilaku proses belajar mengajar serta interaksi antara Dosen Pengampu dengan Mahasiswa. Perilaku proses belajar mengajar serta interaksi antara Dosen Pengampu dengan Mahasiswa merupakan fenomena-fenomea yang akan menjadi dasar model e-PBL. Oleh karenanya, untuk menganalisis data dalam penelitian ini menggunakan analisis fenomenologi, dimana data-data yang diolah merupakan fenomena-fenomena yang terjadi dalam realita social.
\end{abstract}

Kata Kunci: e-PBL, PBL, Akuntansi Manajemen

\section{PENDAHULUAN \\ Latar Belakang}

Kompleksitas perkembangan teknologi informasi akan berdampak pada lingkungan pendidikan dalam hal ini perguruan tinggi. Interaksi sosial memainkan peranan penting dalam pembelajaran. Komunikasi yang bersifat feed back, kecepatan informasi tanpa ada batas waktu dan kemandirian merupakan gambaran kondisi lingkungan pembelajaraan saat ini. Pembelajaran harus didukung suatu teknologi yang akan menggambarkan kompleksitas informasi. E -learning sebagai media pembelajaran ICT yang didukung kompleksitas lingkungan yang akan menghasilkan prinsip-prinsip konstruktivis seperti motivasi diri yang membuat Mahasiswa didik aktif belajar ( Aqda , Hamidi , \& Ghorbandordinejad , 2011)

Model pembelajaran e-PBL diharapkan mampu mendukung tujuan pendidikan di tengah-tengah perkembangan teknologi informasi yang sangat kompleks. Berdasarkan peraturan pemerintah memberikan ruang yang cukup bagi prakarsa, kreativitas, dan kemandirian sesuai dengan bakat, minat, dan perkembangan fisik serta psikologis Mahasiswa didik. e-PBL perlu dirancang sebagai alternatif pembelajaran inovatif pada mata kuliah Akuntansi Manajemen yang memiliki standar kompetensi decision making internal bisnis dan untuk mempersiapkan mahasiswa menghadapi kompleksitas perkembangan teknologi dan sistem informasi akuntansi manajemen (SIAM).

Terbatasnya waktu dikarenakan dalam satu minggu hanya ada 3 sks atau 150 menit untuk mata kuliah akuntansi manajemen, sementara permasalahan atau soal kasus Akuntansi Manajemen relatif banyak, sehingga dibutuhkan pembelajaran yang mandiri. E- pbl mendorong individu untuk bekerja dalam kelompok untuk mencapai hasil yang lebih baik.

\section{RUMUSAN MASALAH}

Berdasarkan latar belakang maka dapat dirumuskan permasalahan dalam penelitian ini adalah bagaimanakah model e-PBL pada mata 
kuliah Akuntansi Manajemen sebagai alternatif pembelajaran inovatif.

\section{LANDASAN PUSTAKA E-LEARNING}

Teori belajar sosial dalam 5 tahun terakhir semakin banyak diteliti. Individu dapat belajar dengan mengamati perilaku orang lain dan hasil dari perilaku tersebut. Namun, kadang kala belajar dapat terjadi dan tidak mengakibatkan perubahan perilaku (Omrod, 1999). Menurut Harley (2001) e-learning merupakan suatu jenis belajar mengajar yang memungkinkan tersampaikannya bahan ajar ke siswa dengan menggunakan media Internet, Intranet atau media jaringan komputer lain. elearning merupakan upaya menghubungkan pembelajar (Mahasiswa didik) yang secara fisik terpisah atau bahkan berjauhan namun dapat saling berkomunikasi, berinteraksi, atau berkolaborasi secara langsung (synchronous) maupun secara tidak langsung (asynchronous).

\section{PROBLEM BASED LEARNING (PBL)}

Salah satu model pembelajaran adalah Problem Based Learning (PBL). Problem Based Learning (PBL) adalah suatu model pembelajaran yang melibatkan siswa untuk memecahkan masalah melalui tahap-tahap metode ilmiah sehingga siswa dapat mempelajari pengetahuan yang berhubungan dengan masalah tersebut dan sekaligus memiliki ketrampilan untuk memecahkan masalah.

PBL merupakan model pembelajaran yang berorientasi pada kerangka kerja teoritik konstruktivisme. Mereka akan memecahkan masalah melalui skill yang mereka miliki dan kerjasama dalam memecahkan masalah maupun untuk memperoleh informasi yang kemudian memprosesnya untuk memperoleh solusi. Untuk meningkatkan kemampuan mereka menapat informasi yang valid dan reliable, dan memudahkan mereka dalam berkomunikasi antar individu maupun kelompok serta dengan dosen, maka dibutuhkan suatu teknologi pembelajaran atau e-learning yang berbasis problem solving atau di sebut e-PBL.

\subsection{E-PROBLEM BASED LEARNING (E- PBL)}

Model pembelajaran e-PBL didasarkan pada model e-PBL dari Barrows dan Myers (1993) dalam. Model pembelajaran E-PBL dimulai dari masalah praktis yang tidak terstruktur yang menempatkan pemecahan masalah dan pembelajaraan kooperatif, mandiri secara on line. Pengembangan model pembelajaran berbasis E-PBL yang merupakan alternatif metode pembelajaran inovatif ditujukan untuk penyajian informasi materi akuntansi manajemen berasarkan kasus riil didasarkan atas informasi selengkaplengkapnya. Model e-PBL didasarkan objek atau topik dari suatu pembelajaran, pada penelitian ini adalah permasalahan terkait akuntansi manajemen dalam suatu internal bisnis yang terdiri dari pengamabilan keputusan atas strategi bisnis biaya yang didasarkan atas aktivitas, activity based manajemen, bugeting, keputusan deferensial cost.

e-PBL memungkinkan untuk kerja kelompok antara mahasiswa dan melatih mereka untuk menerima pendapat mahasiswa lain dalam kelompok yang sama, menyediakan siswa dengan sikap baru dan semangat kompetisi, serta keterampilan untuk menemukan solusi untuk masalah yang mungkin mereka hadapi. Dengan mengikuti langkah-langkah ini , mahasiswa memecahkan masalah dengan menggunakan keterampilan mereka melalui pengumpulan informasi yang disajikan sebelumnya dan memprosesnya untuk mencapai solusi.

\section{METODE PENELITIAN ANALISIS KEBUTUHAN SISTEM}

Tujuan dari fase analisis adalah memahami dengan sebenar-benarnya kebutuhan dari sistem baru dan mengembangkan sebuah sistem yang mewadahi kebutuhan tersebut, atau memutuskan bahwa sebenarnya pengembangan sistem baru tidak dibutuhkan. Tahap analisis sistem bertujuan untuk menjabarkan segala sesuatu yang nantinya akan ditangani oleh perangkat lunak. Aplikasi E-PBL yang dibangun akan digunakan oleh tiga orang aktor yaitu admin, lecture dan student. 
a. Kebutuhan Fungsional, Fasilitas untuk mengelola data admin. Fasilitas untuk mengelola data lecture. Fasilitas untuk mengelola data student. Fasilitas untuk mengelola data kelas.

Pembagian pengguna menjadi tiga kelompok sebagai berikut :

1. Lecture

2. Student

3. Administrator (admin)

b. Kebutuhan Non-Fungsional Operasional: Keamanan. Penggunaan username dan password dalam form login untuk membedakan tipe user termasuk hak akses masing-masing. Interface / Antar muka. Antar muka pemakai atau user interface adalah bagian penguhubung antara program sistem informasi dengan pemakai.

\section{PERANCANGAN SISTEM}

Perangkat lunak pada server yaitu web server yang ditangani oleh script PHP dan database dengan sistem hosting internet. Aplikasi di sisi server berfungsi untuk menangani koneksi client yang berbasis platform android. Setiap request dari client akan ditangani dan dilayani oleh web server. Perangkat lunak pada client (pelayan) dibuat menggunakan platform berbasis web dan internet sebagai penghubung internet untuk melakukan koneksi ke web server.

Langkah perancangan adalah serangkaian tahapan merancang dan membuat basis data. Langkah-langkahnya adalah sebagai berikut.

1. Mempersiapkan alat dan bahan.

2. Membuat rancangan diagram alir data.

3. Normalisasi data.

4. Membuat diagram antar entitas.

5. Mengubah dan menterjemahkan diagram alir program ke dalam tata bahasa pemrograman PHP dengan MySQL.

6. Membuat aplikasi E-PBL berbasis web

7. Menguji Program.

8. Merevisi program bila diperlukan.

\section{ANALISIS KELAYAKAN SISTEM}

\section{a Kelayakan Teknologi}

Kelayakan teknologi berhubungan dengan ketersedian teknologi pembangun sistem dipasaran. Dari segi teknologi, sistem yang diusulkan layak untuk di terapkan di lembaga pendidikan, khususnya Jurusan Akuntansi pada Perguruan Tinggi.

b Kelayakan Hukum

Kelayakan hukum ditinjau dari tujuan penggunaan sistem, legalitas bahan pembuatan sistem serta dari segi informasi yang dihasilkan. Dalam pembuatan website ini digunakan perangkat lunak yang bersifat open source, Oleh karenanya dapat dianggap pembuatan aplikasi E-PBL ini layak secara teknologi.

c Kelayakan Operasional

Sistem ini dikatakan layak secara operasional karena banyak Perguruan Tinggi yang telah memiliki Laboratorium Komputer dan menggunakan jaringan internet.

d kelayakan ekonomi

Dalam kelayakan ekonomi ini, aspek yang dipertimbangkan adalah besarnya dana yang diprlukan untuk mengembangkan sistem serta manfaat yang diperoleh oleh sistem.

\section{HASIL DAN PEMBAHASAN}

Analisis Sistem yang sedang berjalan

Berdasarkan hasil pengamatan penelitian yang telah dilakukan, diketahui bahwa pembelajaran matakuliah Akuntansi Manajemen yang dilaksanakan di beberapa Perguruan Tinggi di Kota Malang dan di Surabaya masih secara konvensional dengan berdasarkan buku atau textbook. Adapun pembelajaran matakuliah Akuntansi Manajemen yang dilakukan di beberapa Perguruan Tinggi di Kota Malang dan di Surabaya juga belum memanfaatkan komputer sebagai media pelatihan dan pembelajaran.

\section{Desain Aplikasi}

Berdasarkan hasil pengamatan yang telah dilakukan, aplikasi E-PBL berbasis web yang dirancang dalam penelitian ini berupa sebuah website yang berfungsi sebagai media pembelajaran matakuliah Akuntansi Manajemen secara online. Aplikasi ini dapat digunakan oleh siapapun dan di manapun berada sehingga sangat memudahkan pengguna tanpa harus melakukan instalasi. Adapun gambaran aplikasi E-PBL yang akan dibuat adalah sebagai berikut: 
1. Aplikasi E-PBL berupa website.

2. Dosen dapat mengelola pelatihan dan pembelajaran Akuntansi Manajemen yang akan dilakukan.

3. Mahasiswa tidak dapat mendaftarkan diri karena telah didaftarkan oleh Dosen.

4. Mahasiswa yang telah terdaftar dapat masuk ke halaman Mahasiswa dan dapat memulai aktivitas pembelajaran.

Berdasarkan gambaran aplikasi E-

PBL yang telah dibuat, desain aplikasi yang akan dibuat sebagai berikut:

1. Halaman pengunjung website

Pengunjung website adalah orang yang mengunjungi website, maka pengunjung website membutuhkan informasi sebagai berikut:

a. Informasi umum yang disajikan kepada pengunjung website memberikan gambaran secara umum mengenai aplikasi e-learning.

b. Informasi mengenai perancang aplikasi tidak lain adalah tim peneliti, yakni Aniek Murniati, S.Sos, MSA dan Aditya Hermawan, SE.Ak, MSA.

c. Form log-in merupakan pintu masuk bagi Dosen dan Mahasiswa serta admin website untuk mengelola masing-masing aktivitasnya.

2. Halaman Dosen

Dosen dapat masuk ke halaman Dosen melalui form log-in. Dosen dapat mengelola semua praktikum yang dilakukannya. Adapun pengelolaan praktikum yang dapat dilakukan oleh Dosen adalah sebagai berikut:

a) Pengelolaan informasi

Dosen dapat mengelola informasi yang dibutuhkan dalam pelatihan dan pembelajaran yang dilakukannya. sebagai berikut:

1) Akun pengguna. Informasi mengenai akun pengguna berisi informasi mengenai username, password serta email Dosen.

2) Identitas instansi Dosen. Informasi mengenai identitas instansi Dosen berisi informasi mengenai Nama Instansi, Alamat Instansi, No. Telp serta No. Fax yang dimiliki. b) Pengelolaan kelasDosen dapat mengelola kelas yang dilakukannya dengan cara menambah, mengubah serta menghapus kelas.

c) Pengelolaan Mahasiswa Dosen dapat mengelola Mahasiswa dengan cara menambah, mengubah serta menghapus Mahasiswa praktikum.

d) Pengelolaan materi Dosen dapat mengelola materi dengan cara menambah, mengubah serta menghapus materi praktikum.

e) Kotak Pesan Kotak pesan berguna sebagai jembatan komunikasi antara Pelatih dengan Mahasiswa.

f) Hubungi Kami Menu hubungi kami berguna sebagai jembatan komunikasi antara Pelatih dengan Admin

3. Halaman Mahasiswa

Mahasiswa yang telah terdaftar oleh Dosen yang bersangkutan dapat masuk ke halaman Mahasiswa dengan cara log-in terlebih dahulu. Fasilitas yang diberikan kepada Mahasiswa adalah sebagai berikut:

a) Akun pengguna. Informasi mengenai akun pengguna berisi informasi mengenai username, password serta email Dosen.

b) Identitas kelas. Informasi mengenai identitas kelas Dosen berisi informasi mengenai Nama Kelas, Hari dan Jam Pelaksanaan, serta Ruang.

c) Unduh materi Mahasiswa dapat mengunduh materi yang diunggah oleh Dosen melalui form unduh file.

d) Pengerjaan materi Pelatihan dan pembelajaran matakuliah Akuntansi Manajemen dilakukan dengan menggunakan konsep studi kasus sebagai berikut:

1) Informasi mengenai perusahaan contoh

2) Informasdi mengenai permasalahan yang terjadi di perusahaan

3) Informasi mengenai teori-teori dalam Akuntansi Manajemen yang relevan dengan permasalahan. 
4) Informasi mengenai contohcontoh penyelesaian kasus di bidang Akuntansi Manajemen

5) Diskusi kelas mengenai penyelesaian kasus

e) Kotak Pesan Kotak pesan berguna sebagai jembatan komunikasi antara Dosen dengan Mahasiswa.

4. Halaman Admin

a) Akun pengguna. Informasi mengenai akun pengguna berisi informasi mengenai username dan password Admin.

b) Kelas. Admin dapat mengetahui informasi mengenai kelas pelatihan Akuntansi Manajemen.

c) Hubungi Kami Menu hubungi kami berguna sebagai jembatan komunikasi antara Dosen dengan Admin

\section{Diagram Aktivitas}

Berdasarkan desain aplikasi yang telah dibuat, maka dapat dibuat diagram aktivitas untuk aplikasi $e$ learning praktikum akuntansi berbasis web sebagai berikut:

Aktivitas Pengelolaan

Dalam aktivitas ini, Dosen,

Mahasiswa dan Admin dapat mengelola pelatihan yang akan dilakukan sebagai berikut:

1. Pengelolaan informasi Dosen dapat mengelola informasi yang terkati dengan praktikum yang dilakukan sebagai berikut:

Gambar 3. Diagram Aktivitas Pengelolaan Informasi oleh Dosen

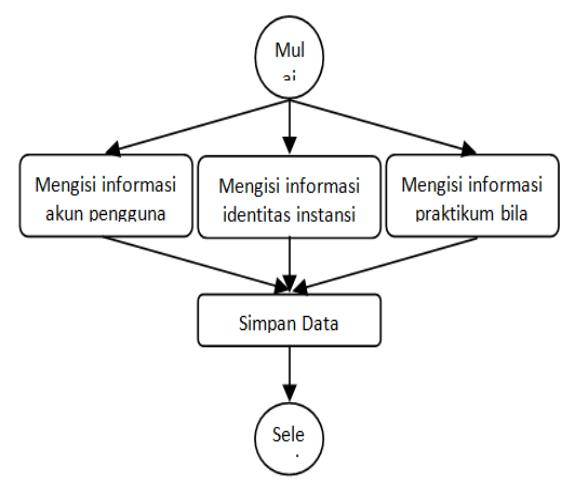

Sumber: Data diolah

Gambar 4. Diagram Aktivitas Pengelolaan Informasi oleh Mahasiswa

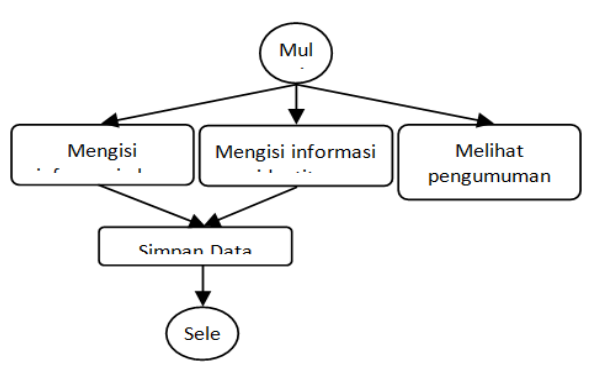

Sumber: data diolah

Gambar 5. Diagram Aktivitas Pengelolaan Informasi oleh Admin

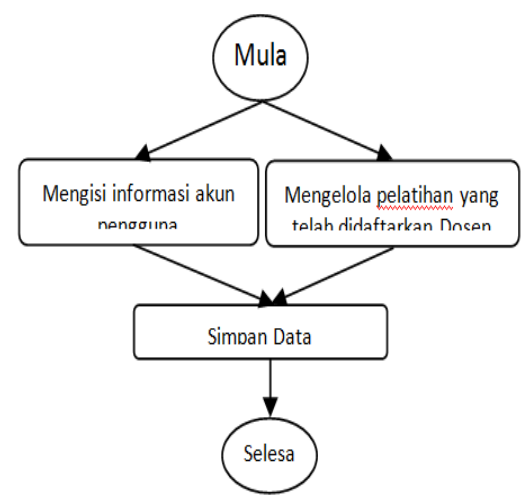

Sumber: data diolah

2. Pengelolaan materi

Pelatih dapat mengelola materi praktikum yang dilakukannya dengan cara menambah, mengubah serta menghapus materi praktikum sebagai berikut:

Gambar 6. Diagram Aktivitas Pengelolaan

Materi 


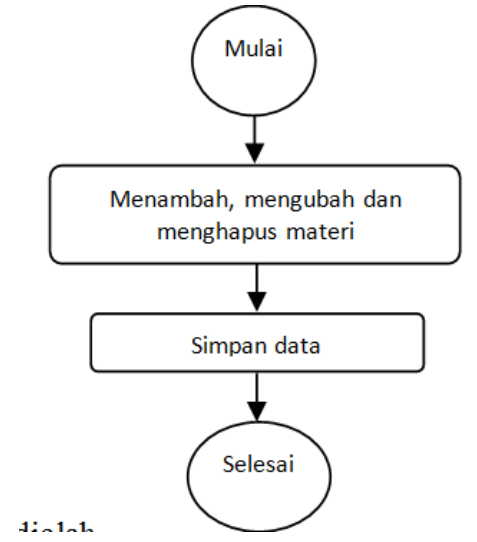

Sumber: data diolah

3. Pengelolaan kelas

Dosen dapat mengelola kelas dengan cara menambah, mengubah serta menghapus kelas sebagai berikut:

Gambar 7. Diagram Aktivitas Pengelolaan Kelas

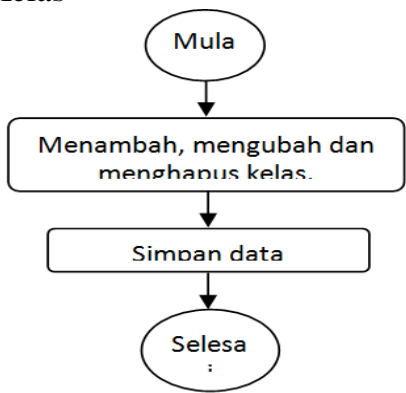

Sumber: data diolah

4. Pengelolaan Mahasiswa

Dosen dapat mengelola Mahasiswa praktikum yang dilakukannya sebagai berikut:

Gambar 8. Diagram Aktivitas Pengelolaan Mahasiswa

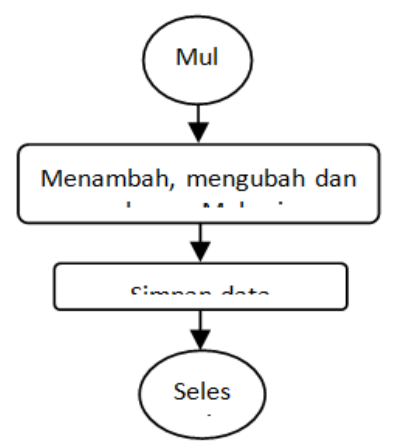

Sumber: data diolah
5. Pengelolaan proses belajar mengajar

Mahasiswa dapat mengerjakan pelatihan Akuntansi Manajemen sebagai berikut:

1. Informasi mengenai permasalahan yang terjadi di perusahaan

2. Informasi mengenai teori-teori dalam Akuntansi Manajemen yang relevan dengan permasalahan.

3. Informasi mengenai contoh-contoh

penyelesaian kasus di bidang Akuntansi Manajemen

4. Diskusi kelas mengenai penyelesaian kasus Diagram aktivitas yang dapat dibuat pada aktivitas pengelolaan proses belajar mengajar adalah sebagai berikut.

Gambar 9. Diagram Aktivitas Pengelolaan

Proses Belajar Mengajar

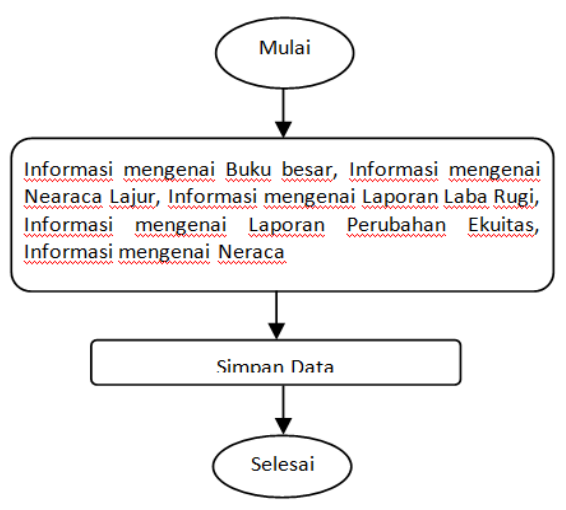

Sumber: data diolah

Aktivitas Komunikasi

Dalam aktivitas ini, Dosen, Mahasiswa dan Admin dapat mengelola pelatihan sebagai berikut:

1. Kotak Pesan Kotak pesan berguna sebagai jembatan komunikasi antara 
Dosen dengan Mahasiswa sebagai berikut:

Gambar 10. Diagram Aktivitas Komunikasi Kotak Pesan Oleh Dosen Dan Mahasiswa

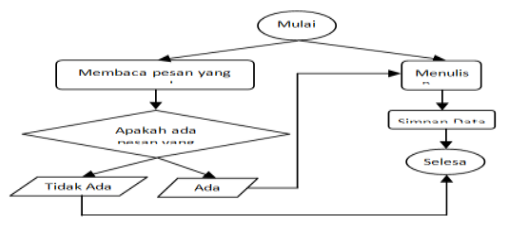

Sumber: data diolah

2. Hubungi Kami

Menghubungi kami berguna sebagai komunikasi antara Dosen dengan Admin sebagai berikut:

Gambar 11. Diagram Aktivitas Komunikasi Kotak Pesan

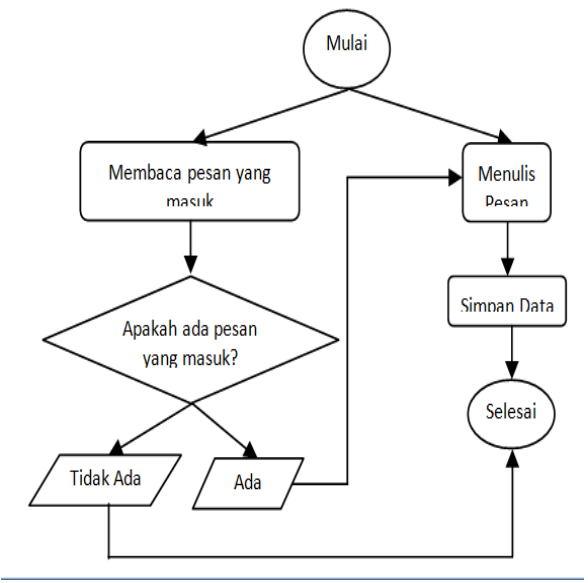

Sumber: data diolah

\section{Perancangan Database}

Berdasarkan diagram aktivitas yang telah dibuat, maka perlu dirancang database sebagai media penyimpanan data. Adapun perancangan database yang dilakukan pada aplikasi E-PBL adalah sebagai berikut:

1. Pembuatan database

Dalam pembuatan database untuk aplikasi e-learning praktikum akuntansi ini, digunakan MySQL sebagai platform database. Database untuk aplikasi E-PBL ini diberi nama praktikum.
Selanjutnya membuat tabel dalam database. Adapun tabel yang dibuat antara lain:

a) Tabel adminweb Tabel ini digunakan untuk menyimpan data adminweb sebagai berikut:

Gambar 12. Struktur Tabel Admin Web

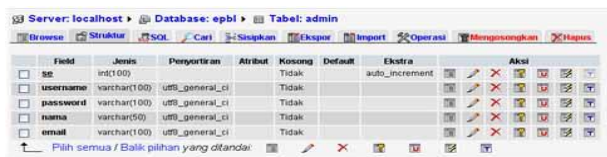

Sumber: data diolah

b) Tabel artikel Tabel ini digunakan untuk menyimpan data artikel yang digunakan sebagai berikut:

Gambar 13. Struktur Tabel Artikel

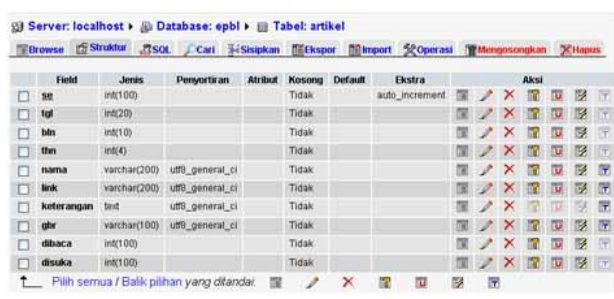

Sumber: data diolah

c) Tabel jurnal Tabel ini digunakan untuk menyimpan data jurnal yang digunakan sebagai berikut:

Gambar 14. Struktur Tabel Jurnal

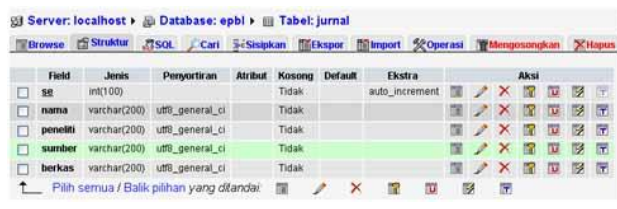

Sumber: data diolah

d) Tabel kasus Tabel ini digunakan untuk menyimpan data kasus yang digunakan sebagai berikut:

\section{Gambar 15. Struktur Tabel Kasus}

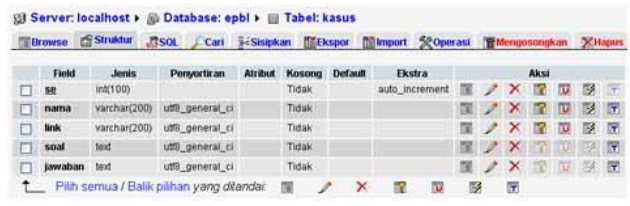

Sumber: data diolah 
e) Tabel kelas Tabel ini digunakan untuk menyimpan data kelas pelatihan sebagai berikut:

\section{Gambar 16. Struktur Tabel Kelas}

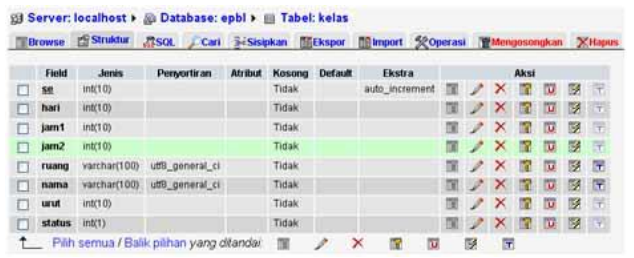

Sumber: data diolah

f) Tabel jawaban Tabel ini digunakan untuk menyimpan data diskusi dalam kelas pelatihan sebagai berikut:

Gambar 17. Struktur Tabel Jawaban

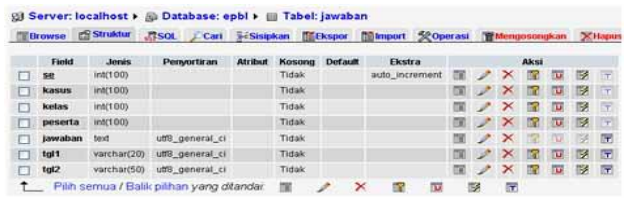

Sumber: data diolah

g) Tabel mahasiswa Tabel ini digunakan untuk menyimpan data mahasiswa peserta kelas pelatihan sebagai berikut:

Gambar 18. Struktur Tabel Mahasiswa

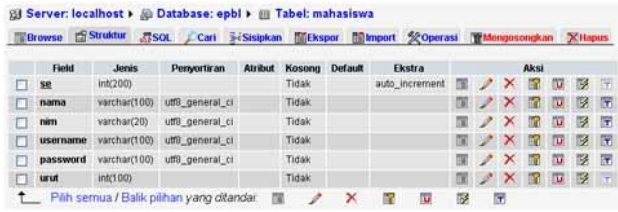

Sumber: data diolah

h) Tabel pengaturan Tabel ini digunakan untuk menyimpan data website yang dilakukan oleh Admin. Adapun struktur tabel sebagai berikut:

Gambar 19. Struktur Tabel Pengaturan

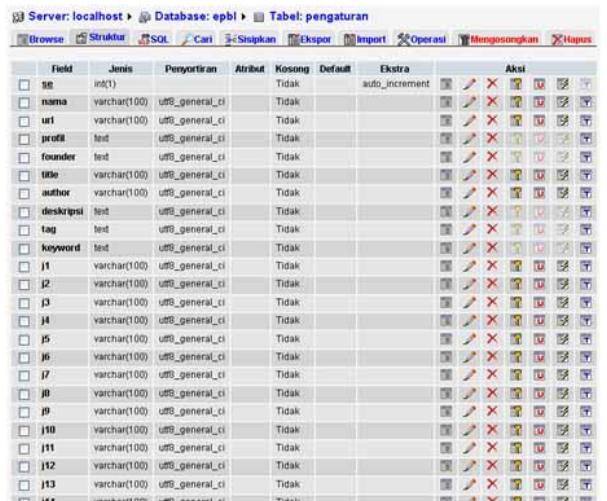

Sumber: data diolah

i) Tabel kunjungan Tabel ini digunakan untuk menyimpan data kunjungan dari pengunjung website. Adapun struktur tabel sebagai berikut:

Gambar 20. Struktur Tabel kunjungan

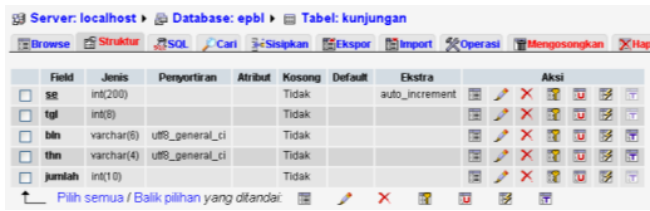

Sumber: data diolah

\section{Implementasi}

Aplikasi e-learning praktikum akuntansi berbasis web dirancang dengan tampilan yang menarik dan mudah untuk dioperasikan. Adapun aplikasi ini dirancang sesuai dengan peruntukan penggunanya, antara lain:

1. Pengunjung

Gambar 21. Halaman Pengunjung 


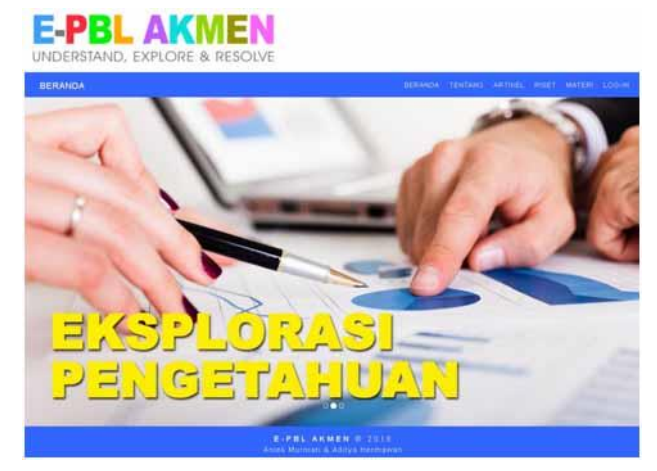

Sumber: www.epblasia.com

2. Dosen

Gambar 22. Halaman Dosen Pada Menu

Akun Anda

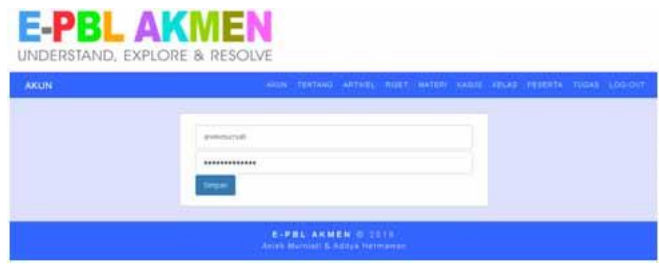

Sumber: www.epblasia.com

Gambar 23. Halaman Dosen Pada Menu

Tentang E-PBL

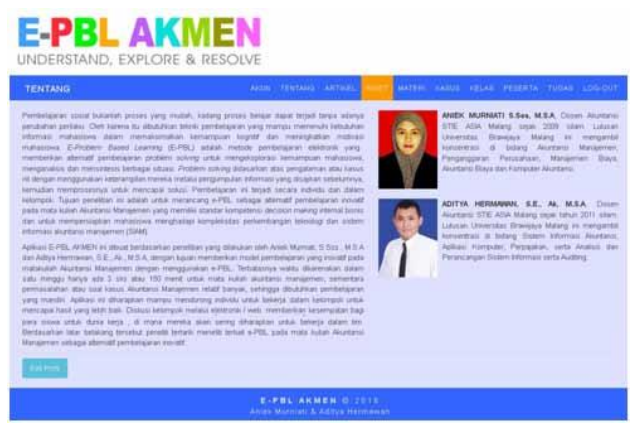

Sumber: www.epblasia.com

Gambar 24. Halaman Dosen Pada Menu Artikel

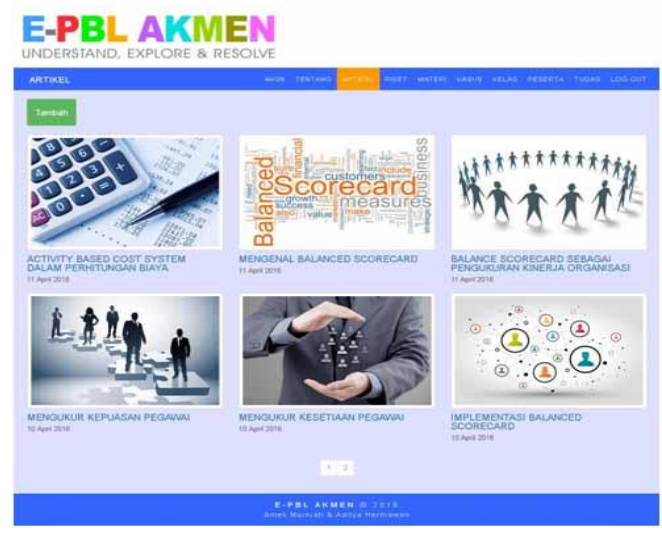

Sumber: www.epblasia.com

\section{KESIMPULAN DAN SARAN}

\section{Kesimpulan}

Studi Tindakan Kelas dilakukan dengan masing-masing peserta diminta membandingkan penggunaan E-PBL dalam Praktikum Akuntansi Manajemen dengan perkuliahan Akuntansi Manajemen yang selama ini dilakukan. Diperoleh hasil bahwasanya penggunaan E-PBL dalam Praktikum matakuliah Akuntansi Manajemen dirasakan lebih efektif. Hal ini dikarenakan peserta tidak sekedar memperoleh materi matakuliah Akuntansi Manajemen, namun juga dapat mempelajari kasus-kasus yang terjadi di dunia Akuntansi Manajemen pada umumnya yang disertai dengan diskusi antara peserta dengan dosen secara online.

Dari segi fitur aplikasi E-PBL matakuliah Akuntansi Manajemen ini, peserta merasa bahwa fitur-fitur yang terdapat di dalamnya mudah untuk digunakan dan familiar dengan perangkat mobile, seperti HP maupun tablet. Dapat disimpulkan bahwa, penggunaan teknologi di dalam perkuliahan Akuntansi Manajemen dengan menggunakan metode PBL dapat mempermudah Mahasiswa untuk memahami materi serta mahasiswa memperoleh pengalaman secara virtual dalam menyelesaikan permasalahan yang terjadi di dunia Akuntansi Manajemen

\section{Saran} penelitian ini adalah diperlukan pengembangan aplikasi E-PBL untuk matakuliah Akuntansi manajemen dengan 
menggunakan aplikasi berbasis android. Hal ini dikarenakan agar pemanfaatan teknologi informasi dalam menunjang kualitas pendidkan menjadi lebih maksimal, mengingat mobilitas pengguna yang semakin tinggi sehingga aplikasi yang berbasis android menjadi lebih ideal.

\section{DAFTAR PUSTAKA}

1. Aqda, M. F., Hamidi F., \& Ghorbandordinejad, F. (2011). The impact of constructivist and cognitive distance instructional design on the learner's creativity. Procedia Computer Science 3, 260-265.

2. Eichelberger, H., \& Laner, C. (2010). Unterrichtsentwicklung via elearning. Oldenbourg, München.

3. Zull, J. E. (2004). The art of changing the brain. Educational Leadership, 62(1), 68-72

4. H.S. Barrows and A.C. Myers, (1993). "Problem-Based Learning in Secondary Schools", Unpublished monograph, Springfield, IL: poblem-Based Learning Institute, Lanphier High School and Southern Illinois University Medical School,

5. Darin E. Harley (2001), Selling ELearning, American Society for Training and Development, , hlm

6. Joo H and Park N, (2015), E-PBL Model Development for Computer Learning Sistem, International journal of multimedia and ubiquistous engineering vol 10 no.3.PP 323-332
7. Khaznal F. Hasan .(2015). Problem Solving Method Based on E-learning System for Engineering Education. Journal of College Teaching and learning System for Engineering education. Fist quarter

8. Omrod, J. E. (1999). Human learning (3rd ed.). Prentice-Hall, Upper Saddle River, NJ

9. Poerwandari. E. K. 1998. Pendekatan Kualitatif dalam Penelitian Psikologi. Lembaga Pengembangan Sarana Pengukuran dan Pendidikan Psikologi (LPSP3) Fakultas Psikologi Universitas Indonesia, Jakarta.

10. Sukardi. 2003. Metodologi Penelitian Pendidikan: Kompetensi dan Praktiknya. Penerbit Bina Aksara, Jakarta

11. Tham, C. M., \& Werner, J. M. (2005). Designing and evaluating e-learning in higher education: A review and recommendations. Journal of Leadership and Organizational Studies, 11(2), 15-26

12. Thorpe, Mary and Gordon, Jean (2012), On line Learning in the workplace, a hybrid model of participation in network propfesional learning, Australasian Journal Of Educational Tecnology 1267-1282.

13. Williams, B K., Stacey C S. Using Information Technology. Pengenalan Praktis Dunia Komputer dan Komunikasi. 7nd Edition. Penerbit Andi. Yogyakarta. 2007 